\section{A\&E DEPARTMENTS}

$T$ he 1991 Public Health Act considerably reduced the number of doctor notifiable conditions in NSW and there has subsequently been a measurable increase in rates of reporting ${ }^{1}$. Hospital Accident and Emergency (A\&E) departments however pose a particular problem. Medical staff working in $\mathrm{A} \& \mathrm{E}$ departments are frequently Resident Medical Officers on short-term rotational attachments. It might be predicted that there would be fewer notifications from them than from more experienced practitioners.

This is of some concern since almost one-third of A\&E department attendances are "comparable to a population which would present to general practice". The high volume turnover of acute conditions being seen makes it likely that these will include a number of notifiable conditions.

A six-month prospective survey was therefore conducted between April and September 1992 in the six Illawarra hospitals with 24-hour A\&E Departments.

\section{FINDINGS}

- Before the start of the survey none of the six participating A\&E departments had made any notifications. Inquiries to the Director/Medical Officer-in-Charge of these departments showed that none held any notification forms, despite supplies having been sent to the Chief Executive Officer/Medical Superintendent of all participating hospitals. Few doctors working in A\&E departments were aware of the revised list of notifiable conditions, or of the necessity to notify them. During the study period only one notification was made from an A\&E department. A subsequent audit of A\&E department day books (April-July 1991) showed at least 15 cases which should have been notified. Given the difficulties of obtaining accurate information from $A \& E$ day books, this is almost certainly an underestimate.

\section{CONCLUSIONS}

Although these 15 cases represent only 0.002 per cent of all $\mathrm{A} \& \mathrm{E}$ cases seen during this period, at least three cases (one of measles and two related cases of gastroenteritis) may have required some public health action. It is concluded that hospital A\&E departments may constitute a possible weak link in Statewide notifiable disease surveillance. All Public Health Units (PHUs) should try to define current practice at hospitals within their Area or Region.

Several NSW hospitals are installing computer systems in their A\&E departments to record details of patient registration and diagnosis. This offers a possible solution to the problem of missed notifications. In the system which has been installed in the six Illawarra hospitals, all notifiable disease diagnoses are "flagged". If one of the diseases is entered in the diagnosis field, a "prompt" will advise that this is a notifiable condition and that the PHU should be contacted by phone, or a completed notification form should be despatched. A weekly print-out can also be sent to the PHU by way of a back-up mechanism, and this will be subject to periodic audit.

\section{David Jeffs, Director \\ Desolie Lovegrove, Public Health Nurse Illawarra Public Health Unit}

1. Anon. Timeliness and Completeness of Reporting. NSW Public Health Bulletin 1992; 3.8.90 ISSN 10347674.

2. National Health Strategy. A Study of Hospital Outpatient and

Emergency Department Services .44 Background Paper 10, Canberra 1992 ISSN 103802722.

\title{
NEWS AND COMMENT
}

\section{PUBLICATION ANNOUNCEMENT}

7 he Register of health data collections second edition October 1992 is available now for $\$ 30$. The Register comprehensively documents data collections administered by the NSW Department of Health Central Administration, including data content, source of data, access and availability of data and reports produced. It is a valuable resource on health related data in NSW and should increase awareness of the range and content of Department of Health data holdings.

Send your request with a cheque or money order payable to the NSW Health Department to: Mrs Judy Milton, Information Centre, NSW Health Department, LMB 961, North Sydney 2059. Phone: (02) 391 9084, fax: (02) 3919070.

\section{ERRATUM}

NSW Public Health Bulletin

Vol 3 No 9, September 1992

Maternal screening for Down's Syndrome

There was a minor error in Table 6. The following is a corrected version of the table:

\section{TABLE 6}

EXPECTED NUMBER OF DOWN'S SYNDROME CASES DETECTED AND MISSED, AND EXPECTED TOTAL NUMBER OF AMNIOCENTESES AND FETUSES LOST FOR VARIOUS POPULATION-BASED MATERNAL SCREENING PROGRAMS, FOR AN AMNIOCENTESIS UPTAKE RATE OF 50 PER CENT (a)

\begin{tabular}{|c|c|c|c|c|c|c|}
\hline \multirow[t]{2}{*}{$\begin{array}{l}\text { Screening } \\
\text { program } \\
\text { (b) }\end{array}$} & \multicolumn{2}{|c|}{$\begin{array}{c}\text { Number } \\
\text { of Down's } \\
\text { pregnan- } \\
\text { cies } \\
\text { detected }\end{array}$} & \multicolumn{2}{|c|}{$\begin{array}{l}\text { Number of } \\
\text { Down's } \\
\text { pregnan- } \\
\text { cies } \\
\text { missed }\end{array}$} & \multirow[t]{2}{*}{$\begin{array}{c}\text { Number of } \\
\text { amnio- } \\
\text { centeses }\end{array}$} & \multirow[t]{2}{*}{$\begin{array}{l}\text { Number of } \\
\text { fetuses lost } \\
\text { (c) }\end{array}$} \\
\hline & No. & $\%$ & No. & $\%$ & & \\
\hline 1 & 18 & 14 & 107 & 86 & 2,293 & 11 \\
\hline 2 & 24 & 19 & 101 & 81 & 4,642 & 23 \\
\hline 3 & 38 & 30 & 87 & 70 & 2,228 & 11 \\
\hline 4 & 42 & 34 & 83 & 66 & 4,363 & 22 \\
\hline 5 & 44 & 35 & 81 & 65 & 6,405 & 32 \\
\hline
\end{tabular}
(a) These figures are based on the maternal age distribution for NSW births $r_{r}$
January-June 1990

b) Screening programs as follows:

1 Maternal age $\geq 37$ years

3 Mriple test screening (incorporating age) only 4 Maternal age $\geq 37$ years plus triple test screening of remainder with triple test
cut-off of $1: 250$

5 Maternal age $\geq 35$ years plus triple test screening of remainder with triple test cut-off of $1: 250$ (c) Expected number of fetuses lost is estimated at 0.5 per cent of total
amniocenteses

\section{MYCOBACTERIAL REFERENCE LABORATORY REPORT - 1991}

During 1991 the Mycobacterial Reference Laboratory at the Institute of Clinical Pathology and Medical Research (ICPMR) at Westmead Hospital performed antibiotic susceptibilities using the Resistance Ratio method.

A total of $248 M$. tuberculosis isolates was tested in 1991 Two hundred and twenty-seven (91 per cent) were fully susceptible to Rifampicin, Isoniazid and Ethambutol. Twenty-one isolates were resistant to a first-line drug. Multiple drug resistance to Isoniazid and Rifampicin occurred in four (1.6 per cent) of isolates tested in 1991.

These results are identical to those for NSW $M$. tuberculosis isolates in 1988.

(A more detailed report has been submitted to the Communicable Diseases Intelligence.)

Tom Gottlieb, William Chiew and Lyn Gilbert, Mycobacterial Reference Laboratory (ICPMR) 